\title{
Erosion and sedimentation in Surtsey island quantified from new DEMs
}

\author{
BIRGIR VILHELM ÓSKARSSON ${ }^{1}$, KRISTJÁN JÓNASSON ${ }^{1}$, \\ GUĐMUNDUR VALSSON ${ }^{2}$ AND JOAQUÍN M. C. BELART ${ }^{2,3}$ \\ ${ }^{1}$ Icelandic Institute of Natural History, Urriðaholtsstræti 6-8, 210 Garðabær, birgir@ni.is (corresponding author). \\ ${ }^{2}$ National Land Survey of Iceland, Stillholt 16-18, 300 Akranes. \\ ${ }^{3}$ Institute of Earth Sciences, University of Iceland, Sturlugata 7 - Askja, 101 Reykjavík.
}

\begin{abstract}
We present data from a photogrammetric study on Surtsey island that generated three new DEMs and orthoimages, two from scanned aerial images from 1967 and 1974 and one from high-resolution closerange images from a survey in 2019. DEM differencing allowed for quantification of the erosion and the sedimentation in the island since 1967. Of the subaerial volcanics, about $45 \%$ of the lava fields have eroded away but only about $16 \%$ of the tuff cones. The prevailing SW coastal wave erosion is evident from the erosive pattern in Surtsey, and the cumulative loss of the coastal margins amounts to $28 \pm 0.9 \times 10^{6} \mathrm{~m}^{3}$ since 1967 , with the current average erosion rate of $0.4 \pm 0.02 \times 10^{6} \mathrm{~m}^{3} / \mathrm{yr}$. Wind deflation and runoff erode the tuff cones and the sediments at the flanks of the cones, with the total volume loss amounting to $1.6 \pm 0.2 \times 10^{6} \mathrm{~m}^{3}$ and the current erosion rate of $0.03 \pm 0.004 \times 10^{6} \mathrm{~m}^{3} / \mathrm{yr}$. A rapid decline in erosion rates characterized the first years post-eruption, and the coastal erosion rate during the winter of 1967-68 was about 5-6 times higher than the current erosion rate due to the thinner and less cohesive nature of the lava apron at the edge of the shelf. The cones eroded at a rate about 2-3 times higher during the first years due to the uncompacted and unconsolidated nature of the cones at that time. The 2019 area of $1.2 \mathrm{~km}^{2}$ and an extrapolation of the current erosion rate fits well with the projected erosion curve of Jakobsson et al. (2000) with the island becoming a tuff crag after approximately 100 years.
\end{abstract}

\section{INTRODUCTION}

Since the emergence of Surtsey island from the sea on November $14^{\text {th }} 1963$, researchers have monitored the island from air, sea and land; systematically documenting its growth during the eruption and its rapid post-eruption erosion (e.g. Einarsson 1965, Thorarinsson 1964, 1966, 1968, Norrman 1970, 1978, 1985, Jakobsson \& Gudmundsson 2003, Jakobsson et al. 2009, Romagnoli \& Jakobsson 2015). During the early stages of Surtsey, the active involvement of seawater with the erupting basalts in the relatively shallow subaqueous environment (130 m depth), generated high energy phreatomagmatic eruptions, the eruption becoming a "type" in the international classification scheme for explosive eruptions known as "Surtseyjan eruption" (Walker 1973). The eruption formed two crescent shaped tephra cones and the primary constituents were intercalated layers of fine and coarse-grained tephra, lithics, accretionary lapilli and fusiform bombs (e.g. Lorenz 1974, Norrman 1974). The non-cohesive tephra, saturated with water, was easily eroded by the waves and washed away with the swash. Two adjacent syneruptions, Syrtlingur and Jólnir, formed ephemeral islands that eroded completely within months and a 
third eruption, Surtla, only formed a seamount (e.g. Thorarinsson 1964, 1966, 1968). With the isolation of the vent area in Surtsey from the sea around April 1964, and the transition to effusive volcanism, two half lava shields formed, one in the Surtungur cone from April 1964 to May 1965 and the other in the Surtur cone from August 1966 to June 1967. Lava entering the sea built a delta of foreset breccia and quenched vitric fragments (Thorarinsson 1968, Kjartansson 1966). Subaerial lava flows that were emplaced on top of the delta extended the coastline to the south and eventually protected the cones from the strong coastal erosion and allowed the tephra to palagonitize and consolidate into tuff. The process of palagonitization turned out to be surprisingly fast and in 10 years about $64 \%$ of the total tephra had already palagonitized, significantly increasing the resistance of the cones to erosion (Jakobsson 1972, 1978).

Despite the lava fields to the south shielding the cones, erosion progresses at a remarkably high rate and in 2019 the maximum coastal retreat reached 720 $\mathrm{m}$ and the total area lost because of erosion since 1965 accumulated to $1.8 \mathrm{~km}^{2}$ (e.g. Norrman 1970, 1978, 1985, Jakobsson et al. 2009). The steep submarine slope of Surtsey volcano and its location at the outer margin of the Iceland shelf create conditions for high energy waves to converge and break full-force on the island (Norrman 1970, 1978). Moreover, strong submarine currents circle the island and wave erosion extends down to depths of $>50 \mathrm{~m}$ as seen in the eroded mounds of Jólnir, Syrtlingur and Surtla (Normann 1970, Jakobsson et al. 2009). Extreme erosion was observed in the first years, notably during the winter of 1967-1968, when the southeastern lava apron retreated by up to $140 \mathrm{~m}$ (Norrman 1970). Before that year or since 1965, the lava field of Surtungur had already retreated by about $150 \mathrm{~m}$ (Thorarinsson 1968). The structure of the lava flows, with closespaced (cm to 1-2 m) vertical and subvertical polygonal joints, makes them susceptible to brittle fracturing and failure under stress. The eroded lava cliffs collapse in large blocks, the talus is grinded by the swash and the boulders are heavily polished and rounded in a matter of days (Thorarinsson 1966). Boulders, gravel and sand are then transported and graded along the shores to a spit north of the island (Thorarinsson 1966, Norrman 1970, Calles et al. 1982), the supply decreasing in recent years leading to a recession of the spit. Erosion of the west coast has led to a steepening of the western side of the tuff cone, the cliff developing a notch with overhanging scarps. Moreover, wind erosion is intense and storms with hurricane force are frequent (Petersen \& Jónsson 2020). With compaction, alteration and subsequent palagonitization of the cones, the erosion rate has decreased, but by 1980 the cones had in localized areas lowered by 1.5-2 m (Ingólfsson 1982) and by up to $4 \mathrm{~m}$ in 2004 (Baldursson \& Ingadóttir 2007). Windblown tephra accumulates in natural traps within the lava fields and around the cones, parts of this tephra originating from the eruptions of Jólnir and Syrtlingur (Thorarinsson 1968). Runoff from seasonal rain erodes rills and gullies in the unconsolidated tephra and sediments. Slumps, mudflows and solifluction mobilize the tephra on the slopes of the cones that accumulate in taluses (Norrman 1970, Calles et al. 1982, Ingólfsson 1982).

Despite the numerous studies documenting the geomorphic change in Surtsey, only minor reference is to the volumetric quantification (e.g. for coastal erosion in Norrman 1970). The total volumetric change was estimated from topographic maps and scanning airborne laser altimetry showing a volumetric decrease of about 25\% from 1968 to 1998 (Garvin et al. 2000). Nevertheless, quantification of the total material loss by erosion and the sediments deposited or redeposited on the island is lacking.

Photogrammetry techniques allow for the generation of high-quality digital elevation models (DEMs) from overlapping nadir and oblique photographs, including from scanned aerial images (e.g. Pedersen et al. 2018, Belart et al. 2019), and nowadays image acquisition with unmanned aerial vehicles (UAVs) is a rapid and cost-effective way to monitor natural environments. Geodetic techniques allow measurements with centimeter precision and geolocation of points in the images yield precise 3D models.

This article presents data processed with digital photogrammetric techniques generating a highresolution DEM for 2019 in addition to two DEMs, one for 1967, the year the eruption ceased, and one for 1974, when the tephra cones had become largely palagonitized and denudation rate had declined significantly. Available is a rich archive of quality photosets with good overlap that can be used to generate DEMs for past years (Landmælingar Íslands 2020, Loftmyndir ehf 2020). Differencing these models yields an overall quantification of the elevation and volume changes since 1967 . In addition, 
we present field observations from a survey in 2019 that aid in the interpretation of the photogrammetric data. Although the comparison in this study is limited to three DEMs, we will here describe the methods and set the stage for future studies quantifying in higher temporal resolution the geomorphic changes in Surtsey.

\section{The Surtsey volcano}

Surtsey is a volcanic island located about $30 \mathrm{~km}$ from the south coast of Iceland and a part of the Vestmannaeyjar archipelago. The eruption of Surtsey began in 1963 and was active intermittently for a period of 3.5 years, terminating in mid-1967 (Einarsson 1965, Thorarinsson 1964, 1966, 1968). The eruption formed a submarine ridge, about 5.8 $\mathrm{km}$ long trending SW-NE, that fed four long-lived eruptions, three of which formed islands and one a seamount. Only Surtsey remains as an island. The Surtsey volcano, with two vents, formed two tephra cones in phreatomagmatic eruptions and two half lava shields in effusive eruptions, with a total area of $2.7 \mathrm{~km}^{2}$. The total volume of Surtsey volcano was estimated to be about $1.1-1.2 \mathrm{~km}^{3}$ of which
$70 \%$ was tephra and 30\% lava (Thorarinsson 1968). The subaerial volume of the island at the end of the eruption in 1967 was estimated to be about 0.1 $\mathrm{km}^{3}$ and the highest point of the island $173 \mathrm{~m}$ a.s.l. (Thorarinsson 1968, Jakobsson et al. 2000). In total, lava comprised about $0.3-0.4 \mathrm{~km}^{3}$ of the total erupted volume, including the submarine foreset breccia but of this volume, only about $0.07 \mathrm{~km}^{3}$ was estimated to be subaerial (Thordarson 2000). The tephra comprised about $0.7-0.8 \mathrm{~km}^{3}$ of which only 0.04 $0.05 \mathrm{~km}^{3}$ was subaerial.

\section{METHODS}

Surtsey was visited in July 18-22, 2019 in the yearly monitoring expedition led by the Icelandic Institute of Natural History. A geodetic survey measured ten ground control points (GCPs) marked with targets (Fig. 1A, label Flagg) along with ten other nearby natural points (Flagg_ex, Nat1), an old benchmark (626, Fig. 1B) and the center of the helipad (THP_C_f). The location of the GCPs are shown in Fig. 2B and the coordinates and labels given in Table 1. The benchmark SURS (Fig. 2B, Sturkell et al. 2009) was occupied with a Trimble NetR5

Table 1. GPS coordinates of ground control points, and their numbers, labels and reference stations. The height $\mathrm{h}$ and $\mathrm{H}$ are in meters, $\mathrm{h}$ is in an ellipsoidal geodetic reference system and $\mathrm{H}$ in a vertical reference system.

\begin{tabular}{|c|c|c|c|c|c|}
\hline Nr. & GCP'S & Lat & Lon & h (GRS80) & H (ISH2004) \\
\hline 1 & 626 & $63^{\circ} 18^{\prime} 00.69806^{\prime \prime}$ & $-20^{\circ} 36^{\prime} 38.08563^{\prime \prime}$ & 118,67 & 53,89 \\
\hline 2 & Flagg1 & $63^{\circ} 18^{\prime} 07.60633^{\prime \prime}$ & $-20^{\circ} 36^{\prime} 48.81971^{\prime \prime}$ & 142,94 & 78,17 \\
\hline 3 & Flagg1_ex & $63^{\circ} 18^{\prime} 07.37060^{\prime \prime}$ & $-20^{\circ} 36^{\prime} 48.98645^{\prime \prime}$ & 141,76 & 76,98 \\
\hline 4 & Flagg2 & $63^{\circ} 18^{\prime} 14.19832^{\prime \prime}$ & $-20^{\circ} 36^{\prime} 55.43431^{\prime \prime}$ & 159,24 & 94,46 \\
\hline 5 & Flagg2_ex & $63^{\circ} 18^{\prime} 13.92611^{\prime \prime}$ & $-20^{\circ} 36^{\prime} 55.48831^{\prime \prime}$ & 159,99 & 95,20 \\
\hline 6 & Flagg3 & $63^{\circ} 18^{\prime} 14.67978^{\prime \prime}$ & $-20^{\circ} 36^{\prime} 23.70404^{\prime \prime}$ & 175,48 & 110,70 \\
\hline 7 & Flagg3_ex & $63^{\circ} 18^{\prime} 14.55741^{\prime \prime}$ & $-20^{\circ} 36^{\prime} 23.33110^{\prime \prime}$ & 175,26 & 110,49 \\
\hline 8 & Flagg4 & $63^{\circ} 17^{\prime} 51.17985^{\prime \prime}$ & $-20^{\circ} 35^{\prime} 54.95749^{\prime \prime}$ & 89,10 & 24,33 \\
\hline 9 & Flagg4_ex & $63^{\circ} 17^{\prime} 50.82319^{\prime \prime}$ & $-20^{\circ} 35^{\prime} 53.84254^{\prime \prime}$ & 90,49 & 25,73 \\
\hline 10 & Flagg5 & $63^{\circ} 17^{\prime} 48.80348^{\prime \prime}$ & $-20^{\circ} 36^{\prime} 18.18708^{\prime \prime}$ & 87,44 & 22,68 \\
\hline 11 & Flagg5_ex & $63^{\circ} 17^{\prime} 48.39999^{\prime \prime}$ & $-20^{\circ} 36^{\prime} 17.21318^{\prime \prime}$ & 87,20 & 22,43 \\
\hline 12 & Flagg6 & $63^{\circ} 18^{\prime} 12.82605^{\prime \prime}$ & $-20^{\circ} 35^{\prime} 35.81968^{\prime \prime}$ & 78,00 & 13,23 \\
\hline 13 & Flagg6_ex & $63^{\circ} 18^{\prime} 12.81001^{\prime \prime}$ & $-20^{\circ} 35^{\prime} 35.05744^{\prime \prime}$ & 79,84 & 15,07 \\
\hline 14 & Flagg7 & $63^{\circ} 18^{\prime} 22.59821^{\prime \prime}$ & $-20^{\circ} 35^{\prime} 48.54144^{\prime \prime}$ & 71,21 & 6,43 \\
\hline 15 & Flagg7_ex & $63^{\circ} 18^{\prime} 22.12830^{\prime \prime}$ & $-20^{\circ} 35^{\prime} 47.89453^{\prime \prime}$ & 71,78 & 7,00 \\
\hline 16 & Flagg8 & $63^{\circ} 18^{\prime} 32.00115^{\prime \prime}$ & $-20^{\circ} 35^{\prime} 55.75310^{\prime \prime}$ & 70,28 & 5,50 \\
\hline 17 & Flagg8_ex & $63^{\circ} 18^{\prime} 32.03681^{\prime \prime}$ & $-20^{\circ} 35^{\prime} 55.79452^{\prime \prime}$ & 70,30 & 5,51 \\
\hline 18 & Flagg9 & $63^{\circ} 18^{\prime} 25.15451^{\prime \prime}$ & $-20^{\circ} 36^{\prime} 11.09302^{\prime \prime}$ & 77,33 & 12,55 \\
\hline 19 & Flagg9_ex & $63^{\circ} 18^{\prime} 25.19063^{\prime \prime}$ & $-20^{\circ} 36^{\prime} 11.08543^{\prime \prime}$ & 77,19 & 12,40 \\
\hline 20 & Nat1 & $63^{\circ} 18^{\prime} 11.59753^{\prime \prime}$ & $-20^{\circ} 36^{\prime} 51.60637^{\prime \prime}$ & 156,14 & 91,36 \\
\hline \multirow[t]{2}{*}{21} & THP_C_f & $63^{\circ} 18^{\prime} 01.04796^{\prime \prime}$ & $-20^{\circ} 35^{\prime} 50.81561^{\prime \prime}$ & 98,84 & 34,07 \\
\hline & Reference & Lat & Lon & h (GRS80) & H (ISH2004) \\
\hline 22 & SURS & $63^{\circ} 18^{\prime} 00.79004^{\prime \prime}$ & $-20^{\circ} 36^{\prime} 20.00381^{\prime \prime}$ & 115,10 & 50,33 \\
\hline 23 & VMEY & $63^{\circ} 2537.16530^{\prime \prime}$ & $-20^{\circ} 17^{\prime} 36.81215^{\prime \prime}$ & 135,28 & 70,31 \\
\hline 24 & SELF & $63^{\circ} 5544.33199^{\prime \prime}$ & $-21^{\circ} 01^{\prime} 56.00393^{\prime \prime}$ & 79,97 & 13,94 \\
\hline
\end{tabular}



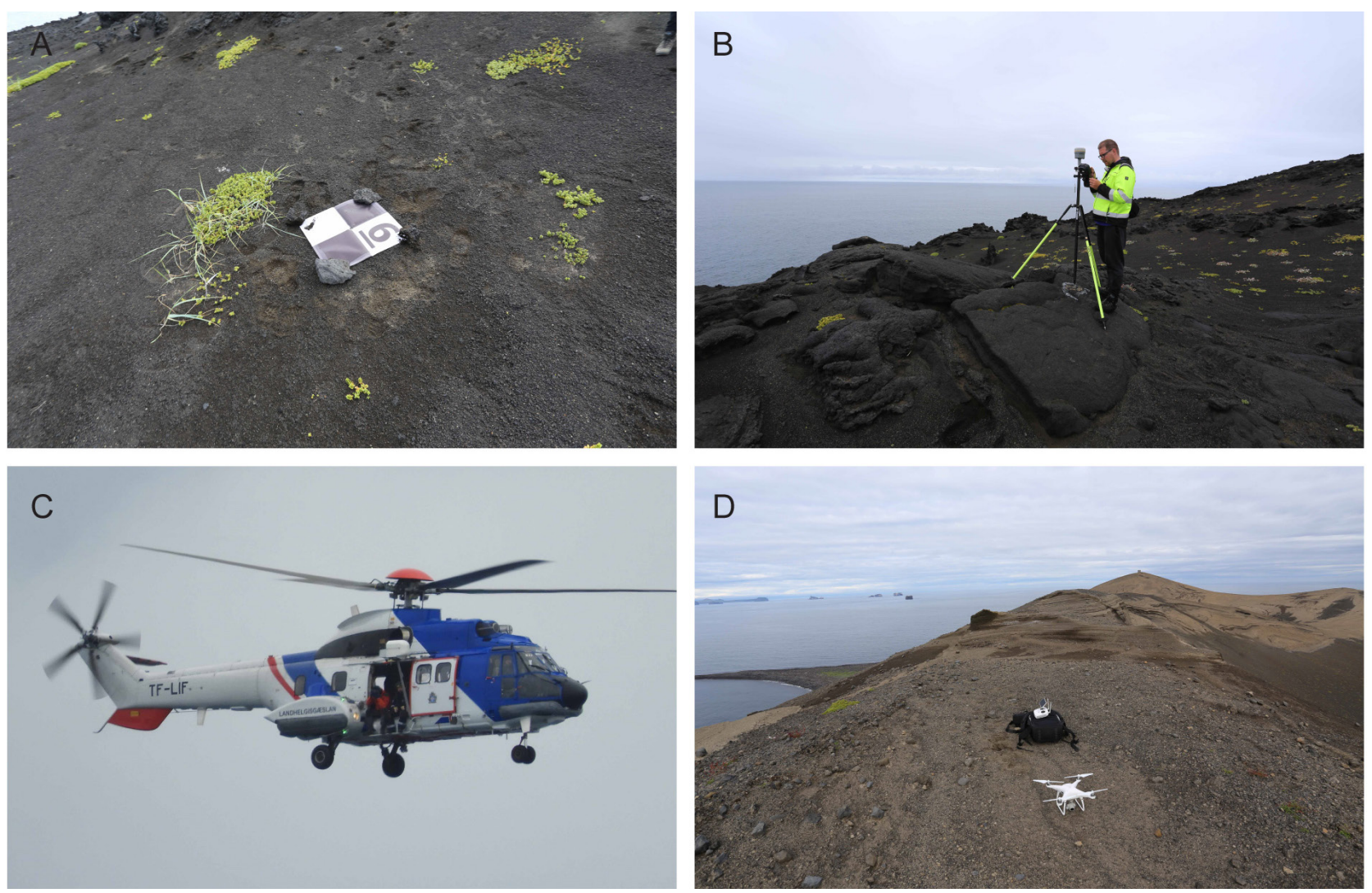

Figure 1. Images from the field work in July 2019. A) Targets used for marking ground control points. B) Surveyor measuring an old benchmark on a lava flow. C) Photographing from the Coast Guard helicopter. Courtesy Barbara Klein. D) The Phantom 4 Pro UAV used in the mapping.

receiver and an NAX3G+C antenna from July 1922. This benchmark served as a base for the GCP campaign. After choosing suitable locations for the GCP signals and the natural ex-center points a FastStatic survey was carried out with a Trimble R10 Global Navigation Satellite System (GNSS) receiver. The occupation time was about 8-12 minutes at each point. Additionally, a Network Real-Time Kinematic (RTK) measurements using the National Land Survey of Iceland's (NLSI's) IceCORS Network were performed at the same GCPs where there was mobile connection. In total 21 points were measured with Fast-Static and 15 points with Network RTK. The GNSS data was processed with a GrafNet GNSS postprocessing software. The first step was to compute an accurate position for SURS. The coordinates were computed using the permanent station VMEY in Heimaey and SELF in Selfoss as reference stations. Then the GCP coordinates were computed using SURS and VMEY as reference stations. A network adjustment was performed, giving $1.2 \mathrm{~cm} \mathrm{rms} \mathrm{(root}$ mean square) in plane and $1.5 \mathrm{~cm}$ rms in height. Comparison with the Network RTK measurements showed good agreement where the biggest difference was $1.4 \mathrm{~cm}$ in plane and $2.7 \mathrm{~cm}$ in height. Finally, ISH2004 heights were computed using NLSI's geoid model in the Cocodati transformation application.

Geotagged nadir and oblique photographs were taken from a helicopter with a Nikon D850 45 MP with a $35 \mathrm{~mm}$ Zeiss Distagon lens with a B+W $72 \mathrm{~mm}$ MRC Nano XS-pro filter (Fig. 1C). Photographing was also done from a DJI Phantom 4 Pro drone mounted with a FC6310 20 MP camera and an 8.8 mm lens (Fig. 1D). About 1500 nadir and oblique photographs were taken at altitudes of $80-340 \mathrm{~m}$. The average ground sampling distance of the images (GSD) was $5.49 \mathrm{~cm} /$ pixel.

The field and analytical workflow is described in (Sørensen \& Dueholm 2018) and the data processed in Pix4Dmapper (Pix4Dmapper 2019), a commercial digital photogrammetric software. The resulting products were a DEM, an orthoimage, a point cloud and a mesh model (Fig. 2A-B and 4A-D).

The Pix4Dmapper reported optimum results for all processing steps of the 2019 model. Georeferencing was achieved with 18 GCPs with an error less than 

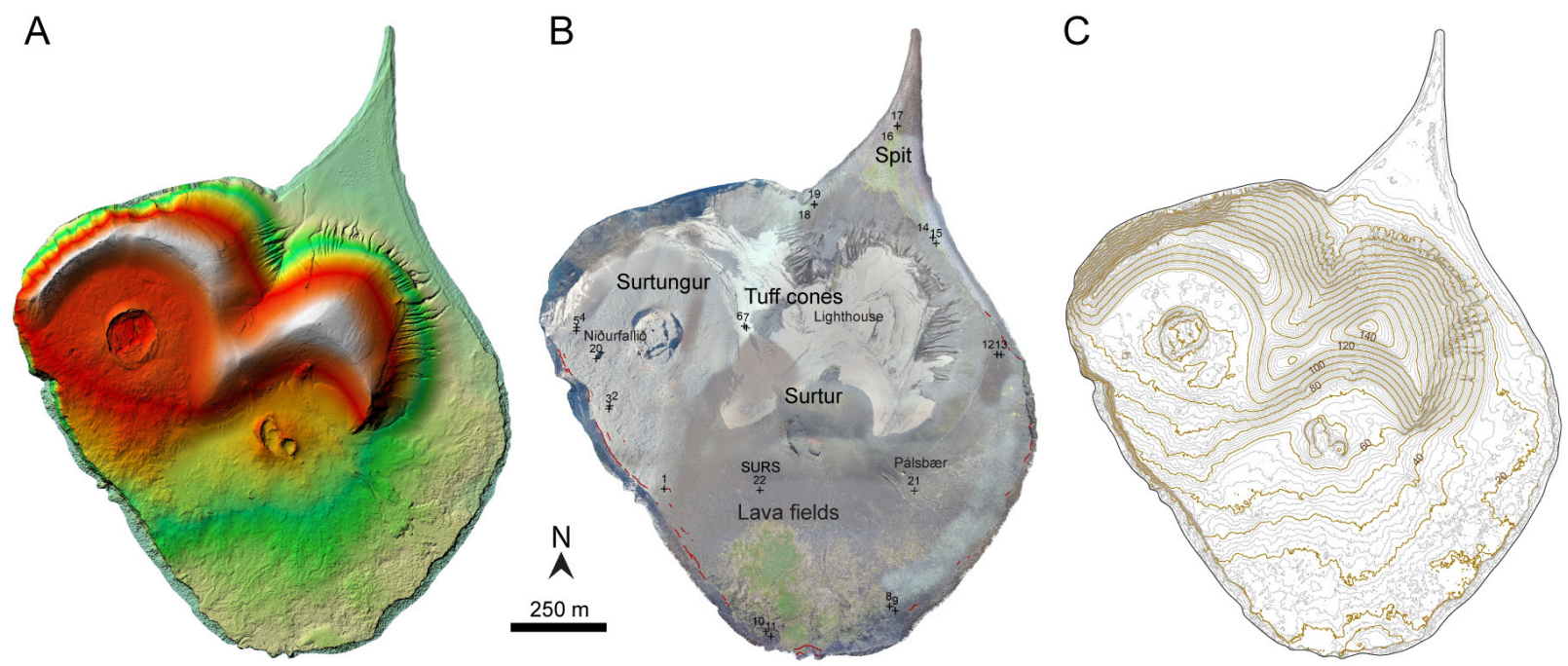

Figure 2. The products of the 2019 photogrammetry project. A) A DEM of Surtsey in 10x10 cm, visualized as a color-coded shaded relief. B) An orthophoto of Surtsey showing the main geologic formations on the island, the location of reference points as the hut Pálsbær, the lighthouse and the "Niðurfallið" (Icelandic for "drain pipe", a pit crater above a lava tube), the locations of the GCPs (crosses, see locations of numbers in Table 1) and the crack systems from wave loading at the margins of the lava fields (red lines). C) Contour lines generated from the DEM with line interval of $2 \mathrm{~m}$ (gray) and $10 \mathrm{~m}$ (yellow).

two times the average GSD ( $\mathrm{rms}$ of $0.061 \mathrm{~m}$ ). The number of 3D points had an average density of $29 \mathrm{pts}$ $\mathrm{m}^{-3}$. The point cloud was linearly interpolated into a $10 \times 10 \mathrm{~cm}$ DEM, and an orthoimage was created in $5 \times 5 \mathrm{~cm}$. Both DEM and orthoimage were projected in the ISN2016 reference system. The DEM displayed minor artefacts, only small holes from shadows in the south cliff region and on the west slope of Surtungur tuff cone. The resulting DEM was compared to the GPS points surveyed, yielding a median elevation difference of $0.01 \mathrm{~m}$ and a Normalized Mean Absolute Deviation (NMAD, Höhle \& Höhle, 2009) of $0.11 \mathrm{~m}$.

The aerial photographs of 1967 and 1974 were processed following the method described in Belart et al. (2019). This consists of a semi-automatic workflow where the photogrammetric software MicMac (Pierrot Deseilligny \& Clery 2011; Rupnik et al. 2017) is used, and the only input required is the digitization of GCPs. The GCPs were extracted from the 2019 DEM and orthoimage, and additional GCPs were included at different locations along the coast of the 1967 and 1974 datasets, assumed to have zero elevation. As a result, DEMs in $2 \times 2$ $\mathrm{m}$ and orthoimages in $50 \times 50 \mathrm{~cm}$ were created from the 1967 and 1974 datasets. Gaps and outliers in the resulting DEMs and orthoimages were due to bad matching because of shadows or surfaces such as homogeneous tephra. These areas were manually masked out for visualization (Fig. 3), and for volume calculation they were linearly interpolated using a Delaunay triangulation.

The volume of the different lithologies on the island in 2019, that include the lava fields, the tuff cones, the cone sediments (sediments on the flanks of the tuff cones comprised of aeolian sand, talus and debris fans) and the spit sediments, were calculated in Pix4Dmapper using a reference baseplane of zero $m$ elevation while the base of the cone sediment was triangulated. The areal distribution of each lithology was based on field reconnaissance, nadir images and the geological maps of Sveinn Jakobsson (Náttúrufræðistofnun Íslands, Reykjavík, unpublished maps of Surtsey in 1:5,000: 1967, 1977, 2016). The erosion and sedimentation volumes were calculated from the DEM differences (dDEMs) of 1967-1974 and 1974-2019 (Fig. 3). To quantify the processes, i.e. coastal erosion, wind and runoff erosion as well as sedimentation, we specified areas based on the results of the dDEMs and the different lithologies on the geological maps (Fig. 3 and Table 2 ). The pixels of the analyzed area were summed up and multiplied by the pixel area (e.g. McNaab et al. 2019). Uncertainties in elevation of the DEMs of 1967 and 1974 and the volume calculations were estimated assuming an uncertainty of $1 \mathrm{~m}$ for the marginal areas (areas 1, 2 and 5 in Fig. 3) and 
Table 2. Areas and volumes of Surtsey island from the 1967, 1974 and 2019 DEMs , and of the main lithologies measured from the 2019 DEM and point cloud. Below are the volume changes from the 1967-1974 and 1974-2019 dDEMs. The area for each location numbered 1-7 is shown in Figure 3.

\begin{tabular}{|c|c|c|c|c|}
\hline DEM & Month & Area $\mathbf{m}^{2}$ & Volume $\left(x 1^{6} \mathrm{~m}^{3}\right)$ & Vol\% of 1967 \\
\hline 2019 & 19-21 July & 1251310 & $70.69 \pm 0.12$ & 71,0 \\
\hline 1974 & 16 July & 2117962 & $90.71 \pm 2.12$ & 91,1 \\
\hline 1967 & 18 July & 2659034 & $99.63 \pm 2.66$ & 100,0 \\
\hline \multicolumn{2}{|c|}{2019 DEM and point cloud } & Area $\mathbf{m}^{2}$ & Volume $\left(x \mathbf{1 0}^{6} \mathrm{~m}^{3}\right)$ & Vol\% of 2019 \\
\hline Lava fields & July & 660976 & $31.8 \pm 0.06$ & 44,8 \\
\hline Tuff cones & July & $443220 *$ & $38.6 \pm 0.04$ & 54,4 \\
\hline Spit sediment & July & 122542 & $0.3 \pm 0.005$ & 0,4 \\
\hline Sediment & July & 153930 & $0.3 \pm 0.008$ & 0,4 \\
\hline \multicolumn{5}{|c|}{ Volume change 1967-1974 } \\
\hline & Area $\mathbf{m}^{2}$ & Volume $\left(x \mathbf{1 0}^{6} \mathrm{~m}^{3}\right)$ & & Avg./yr $\left(x 1^{6} 0^{6} \mathrm{~m}^{3}\right)$ loss \\
\hline & & Positive & Negative & \\
\hline 1-Cliff lava & 491435 & $0.026 \pm 0.036$ & $-6.999 \pm 0.553$ & $-0.999 \pm 0.079$ \\
\hline 2-Cliff tephra/tuff & 121284 & $0.011 \pm 0.009$ & $-2.658 \pm 0.113$ & $-0.380 \pm 0.016$ \\
\hline 3-Tephra/tuff cones & 408544 & $0.336 \pm 0.117$ & $-0.248 \pm 0.088$ & $-0.035 \pm 0.013$ \\
\hline 4-Lava fields & 1122572 & $0.430 \pm 0.280$ & $-0.417 \pm 0.281$ & $-0.060 \pm 0.04$ \\
\hline 5-Spit sediment & - & $0.181 \pm 0.048$ & $-0.507 \pm 0.244$ & $-0.072 \pm 0.035$ \\
\hline 6-Sediment & 216916 & $0.447 \pm 0.091$ & $-0.091 \pm 0.018$ & $-0.013 \pm 0.003$ \\
\hline 7-Scoria cones & 32928 & $0.033 \pm 0.014$ & $-0.011 \pm 0.002$ & $-0.0016 \pm 0.0003$ \\
\hline Total & & $1.464 \pm 0.595$ & & \\
\hline Total & & & $-10.931 \pm 1.299$ & $-1.562 \pm 0.186$ \\
\hline Net loss & & & $-9.467 \pm 1.894$ & $-1.352 \pm 0.271$ \\
\hline \multicolumn{5}{|c|}{ Volume change 1974-2019 } \\
\hline 1-Cliff lava & 615928 & $0.031 \pm 0.035$ & $-15.484 \pm 0.693$ & $-0.344 \pm 0.015$ \\
\hline 2-Cliff tuff & 112809 & $0.003 \pm 0.001$ & $-2.931 \pm 0.113$ & $-0.065 \pm 0.003$ \\
\hline 3-Tuff cones & 287104 & $0.011 \pm 0.005$ & $-0.922 \pm 0.276$ & $-0.020 \pm 0.004$ \\
\hline 4-Lava fields & 535010 & $0.055 \pm 0.078$ & $-0.199 \pm 0.188$ & $-0.004 \pm 0.004$ \\
\hline 5-Spit sediment & - & $0.051 \pm 0.027$ & $-0.735 \pm 0.214$ & $-0.016 \pm 0.005$ \\
\hline 6-Sediment & 191071 & $0.257 \pm 0.046$ & $-0.384 \pm 0.063$ & $-0.009 \pm 0.001$ \\
\hline 7-Scoria cones & 31953 & $0.003 \pm 0.003$ & $-0.034 \pm 0.014$ & $-0.0008 \pm 0.0003$ \\
\hline Total & & $0.409 \pm 0.193$ & & \\
\hline Total & & & $-20.689 \pm 1.422$ & $-0.459 \pm 0.032$ \\
\hline Net loss & & & $-20.280 \pm 1.615$ & $-0.451 \pm 0.036$ \\
\hline
\end{tabular}

* Sediments around the tuff cones included in area.

$0.5 \mathrm{~m}$ for central areas (areas 3, 4, 6 and 7). This uncertainty is estimated based on similar datasets processed in Iceland between 1960s and 1970s, which have uncertainties ranging from $0.3 \mathrm{~m}$ to $0.8 \mathrm{~m}$ (Magnússon et al. 2016, Belart et al. 2019), since no unchanged terrain can be used in Surtsey as a proxy for uncertainties. The lower uncertainty of $0.5 \mathrm{~m}$ is assumed based on the difference of elevation observed in areas with little changes (Fig. 3). The uncertainty of the DEM of 2019 was estimated as $0.2 \mathrm{~m}$, based on the difference between the DEM and the GPS measurements. For simplicity, the uncertainty neglects errors due to subsidence post-eruption and errors in the definition of the "zero" elevation at the sea level, which do not consider effects of tides or changing waves during the acquisition of photographs. The subsidence post-eruption in Surtsey is attributed to a compaction of the volcanic material and the underlying sediments and a down sagging of the volcano, totaling $1.1 \mathrm{~m}$ in 1991 (greatest in the Surtur vent area), followed by a continuous subsidence rate of approximately $1 \mathrm{~cm} / \mathrm{yr}$ until 2000 (Moore et al. 1992, Sturkell et al. 2009). For the purpose of this study, this subsidence, that could amount to $1-2 \%$ of the original volume, was not included in the interpolation in order not to skew the quantification of the erosive and sedimentary products.

\section{RESULTS}

Area and volume calculations from the DEMS

The total area and volume calculations of the DEMs are given in Table 2. In addition, we include the calculated area and volume from the 2019 DEM 


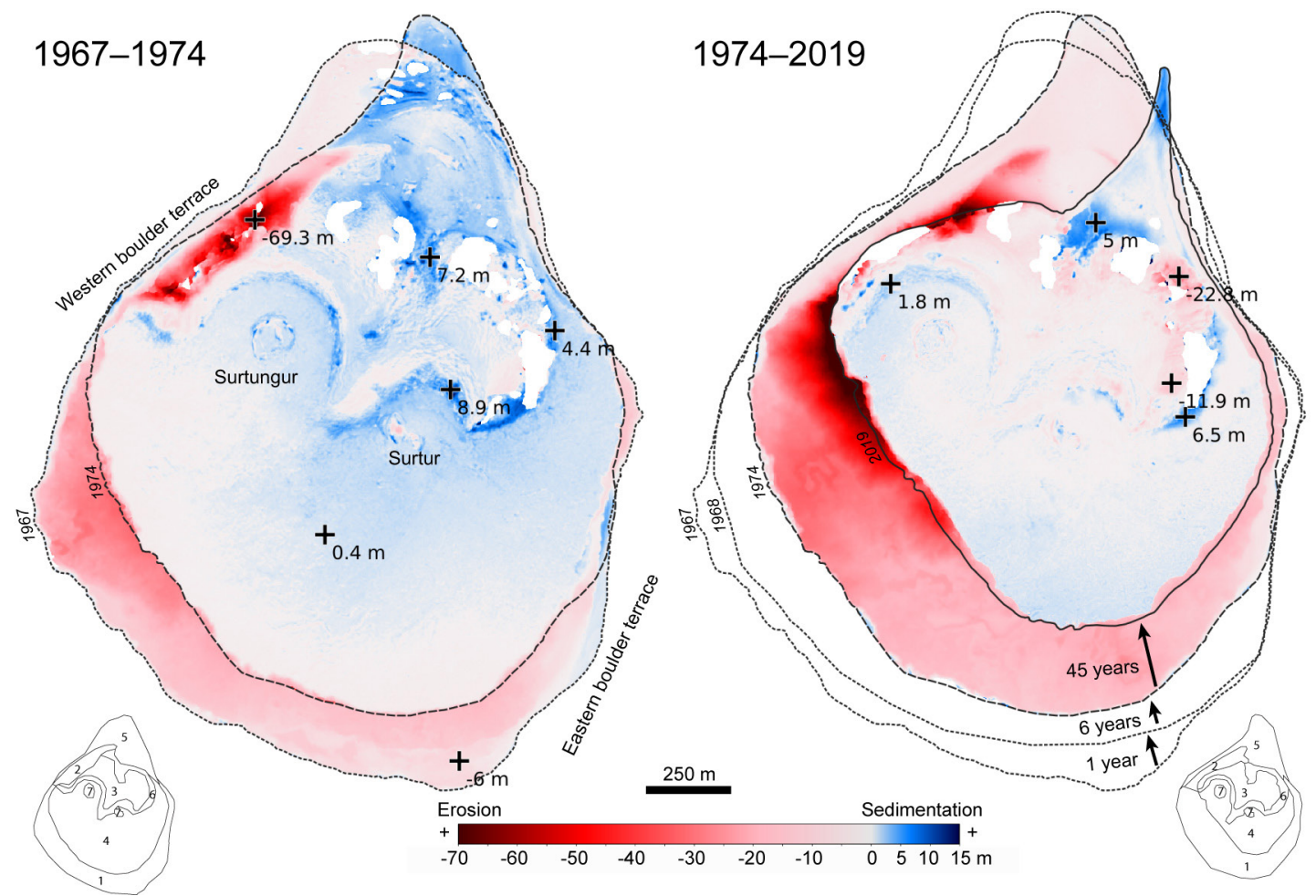

Figure 3. Elevation differences from the 1967-1974 and 1974-2019 dDEMs showing the main geomorphic changes in Surtsey since the end of the eruption. The colors give the values in meters of material eroded (red) or deposited (blue). The thickness in meters for selected locations (crosses) is shown for reference. Stippled lines show the areal change since 1967 and arrows the respective years between them. The numbers in the overview maps on the sides show the areas used in the calculations in Table 2.

and point cloud for the lava fields, the tuff cones, the sediments around the cones and the spit.

\section{Difference in elevation}

The positive and the negative volume change for the dDEMs of the 1967-1974 models and the 1974- 2019 models is shown in Figure 3. The values reflect the volume lost by erosion or gained with sedimentation and are in good agreement with documented field observations. The 1967-1974 dDEM shows the extensive erosion of the southern lava fields (totaling about $0.49 \mathrm{~km}^{2}$ ) and the erosion of the northwestern part of the tephra/tuff cones (the cones were undergoing palagonitization during this period and changing from tephra to cemented tuff and are thus referred to here as tephra/tuff cones). It shows the sedimentation and the erosion of the southeastern boulder terrace that eroded away in 1968 (Norrman 1970) as well as the shrinking and migration to the east of the spit. It also shows marked erosion of the inner flanks of the tephra/tuff craters and the early sediment accumulation at the base of the cones $(4-9 \mathrm{~m})$. Evidence of sedimentation and possibly mass wasting is seen in the positive areas of the upper rims and northern flanks of the tephra/ tuff cones. A negative area inside the scoria cone of Surtur was verified on the aerial photographs to be the collapse of a small intra-crater scoria cone, the remains of which can still be found inside the larger Surtur scoria cone.

The 1974-2019 dDEM shows extensive erosion of the southern lava fields (totaling about $0.61 \mathrm{~km}^{2}$ ) and the west side of Surtungur (Fig. 3). Negative areas of the tuff cones show pronounced erosion, especially on the eastern side where the gullies are found. Continuous accumulation of sediments is seen on the northern and eastern flanks of the tuff cones and within the craters. The spit continues to undergo recession and eastward migration. The crest of the scoria cones has undergone minor degradation.

It is worth presenting a few additional observations from the field survey in 2019. From oblique images and the mesh model we observe and measure a notch 2-4 $\mathrm{m}$ deep and 14-90 $\mathrm{m}$ high in the western tuff cone (Fig. 4A). Also seen are cave formations $10-30 \mathrm{~m}$ deep and 10-20 $\mathrm{m}$ high in the 

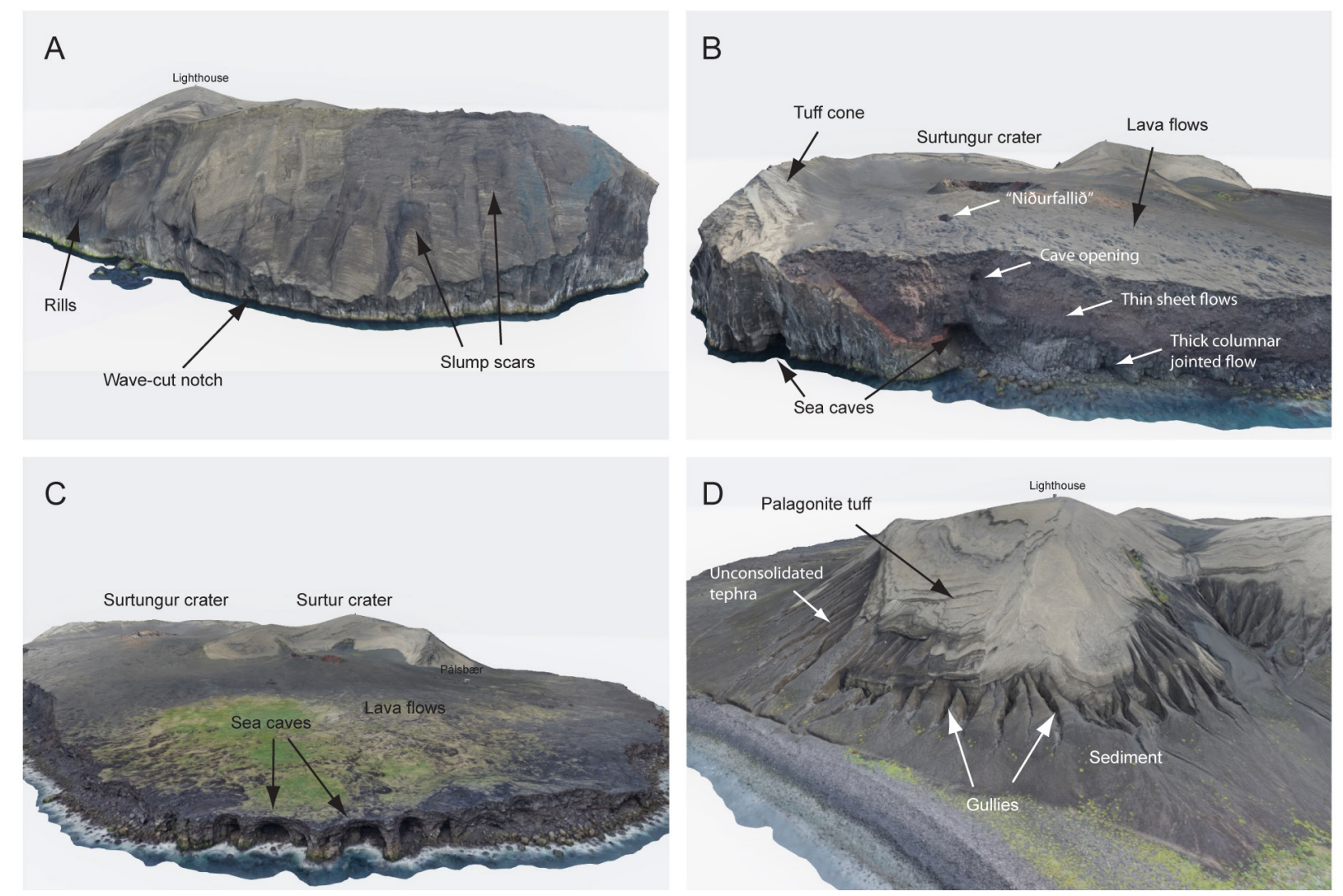

Figure 4. Images of the mesh model showing erosion features in Surtsey (the mesh model can be viewed at www.ni.is/surtsey-i-thrividd). A) The NW side of Surtsey showing the notch and slump scars in the Surtungur tuff cone. Field of view is about $800 \mathrm{~m}$. B) The SW side of Surtsey showing the sea caves forming in the tuff cone and at the contact between the tuff cone and the lava flows. Field of view is about $600 \mathrm{~m}$. C) The SE side of Surtsey showing the sea caves in the apron of the Surtur lava field. Field of view is about $1.2 \mathrm{~km}$. D) The NE side of Surtur tuff cone showing the gullies forming at the boundary between the unconsolidated sediments (dark brown) and the palagonitized tuff (light brown). Field of view is about $700 \mathrm{~m}$.

tuff and the lava flows (Fig. 4B-C). A conspicuous system of cracks was mapped parallel to the cliffs along the entire southern coast, most $1-5 \mathrm{~m}$ into the lava fields, up to $170 \mathrm{~m}$ long, and a less conspicuous system of cracks can be found $25-47 \mathrm{~m}$ further into the fields in the western area (Fig. 2B and 5A). The cracks in the southern coastal areas above the caves in Figure 4C, are inflation clefts that formed during the emplacement of the lava flows and are not fractures from wave loading (Fig. 5B). The inner south flank of Surtur tuff crater, which is now mostly palagonitized, has developed a large $30 \mathrm{~m}$ wide and 1-2 $\mathrm{m}$ deep wind-eroded pothole (Fig. 5C). The unconsolidated tephra and sediment on the eastern and northeastern flanks of Surtur is cut by numerous (>50) 3-30 m wide, 2-14 $\mathrm{m}$ deep and 20 to over 300 $\mathrm{m}$ long gullies. At one location rills merge to form a prominent $10-20 \mathrm{~m}$ deep gully at the boundary between the palagonitized part of the cone and the sediment (Fig. 4D). A standing 4-5 $\mathrm{m}$ feeder dyke on the eastern slopes of Surtur shows the extent of the erosion into the palagonitized Surtur tuff cone (Fig. 5D), and consolidated material around hydrothermal fissures standing $0.5-1 \mathrm{~m}$ above their surroundings on top of Surtungur cone show the minimum extent of the erosion since the formation of the fissures at those locations. Driftwood accumulates mostly on the western boulder shore on the spit, $20-55 \mathrm{~m}$ inland and at $4 \mathrm{~m}$ a.s.l. A few pieces of driftwood are found $100 \mathrm{~m}$ away from the shore on a small sand and gravel patch where plants thrive.

\section{Output and input quantified}

Quantification of the erosion and sedimentation from the dDEMs is given in Table 2 for the specified areas shown in Figure 3. Noteworthy is the high erosion for the first 7 years from 1967-1974 totaling $10.9 \pm 1.3 \times 10^{6} \mathrm{~m}^{3}$, of which $9.7 \pm 0.7 \times 10^{6} \mathrm{~m}^{3}$ is from coastal wave erosion of areas 1 and 2. Total sedimentation or resedimentation is also high or 

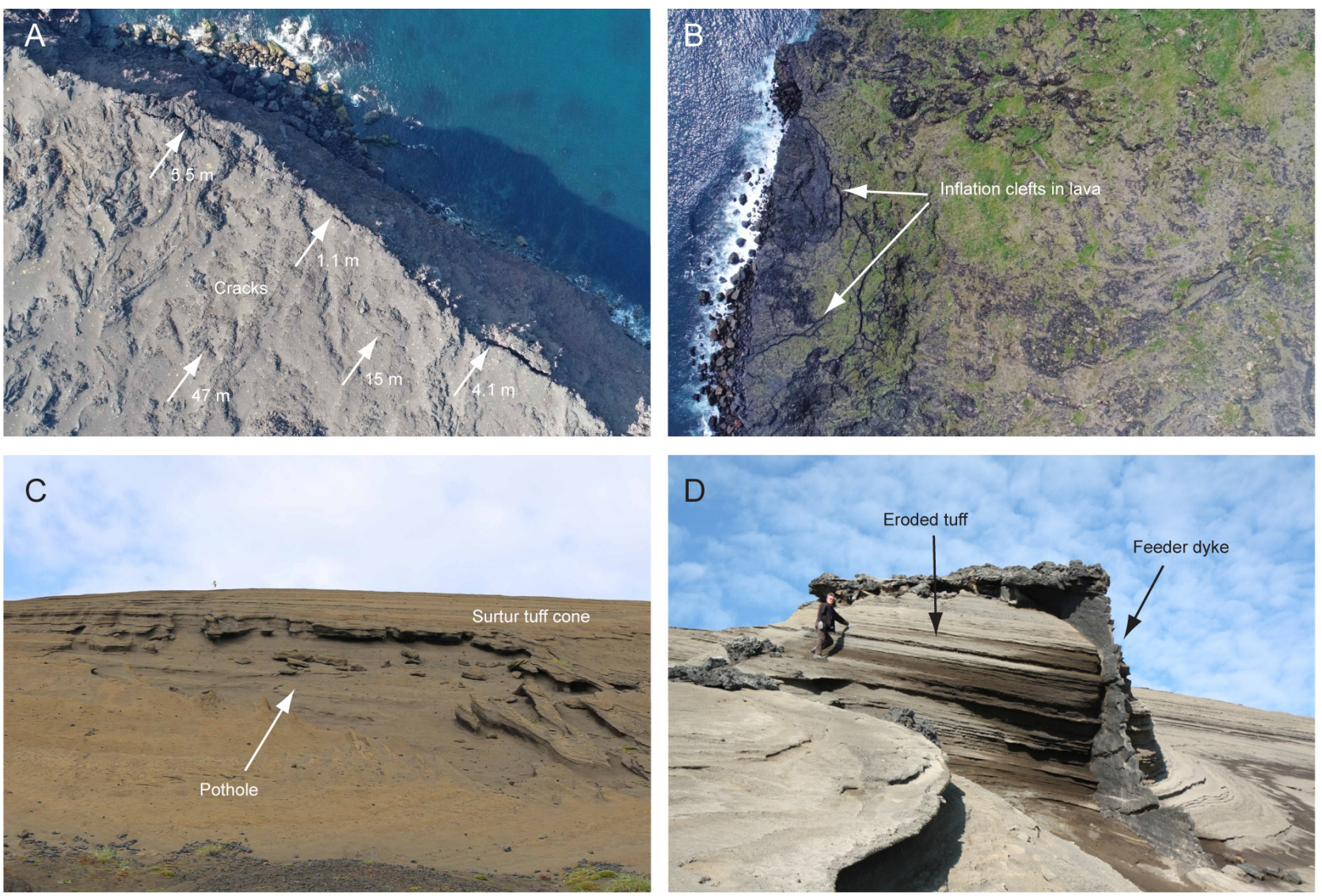

Figure 5. Close-up images of erosion features. A) Cracks along the coastal lava edges. The arrows show the location of the cracks and their respective distances from the margins. B) Inflation clefts in the lava apron. C) Wind-eroded pothole in the inner slopes of Surtur tuff crater. D) Erosion of the Surtur palagonite tuff exposing a feeder dyke. Person for scale.

about $1.5 \pm 0.6 \times 10^{6} \mathrm{~m}^{3}$. Wind and runoff erosion of the tephra/tuff cones and the sediments in areas 3 and 6 amounts to $0.3 \pm 0.1 \times 10^{6} \mathrm{~m}^{3}$ while sedimentation amounts to $0.8 \pm 0.2 \times 10^{6} \mathrm{~m}^{3}$. The spit (area 5) lost $0.5 \pm 0.2 \times 10^{6} \mathrm{~m}^{3}$ and about $0.2 \pm 0.05 \times 10^{6} \mathrm{~m}^{3}$ was redeposited. Only average erosion rates are given and they do not reflect the rapid decline in erosion during the first year's post-eruption.

Erosion rate decreases significantly from 19742019 with a total loss of $20.7 \pm 1.4 \times 10^{6} \mathrm{~m}^{3}$, of which $18.4 \pm 0.8 \times 10^{6} \mathrm{~m}^{3}$ was by coastal wave erosion of the cliffs in areas 1 and 2 at rates of $0.4 \pm 0.02 \mathrm{~m}^{3} /$ $\mathrm{yr}, 1.3 \pm 0.3 \times 10^{6} \mathrm{~m}^{3}$ by wind and runoff erosion of the partly palagonitized tuff cone and the sediments in areas 3 and 6 at rates of $0.03 \pm 0.005 \mathrm{~m}^{3} / \mathrm{yr}$. The spit lost $0.74 \pm 0.2 \times 10^{6} \mathrm{~m}^{3}$, eroding at a rate of $0.016 \pm 0.005 \mathrm{~m}^{3} /$ yr. Total sedimentation was about $0.41 \pm 0.2 \times 10^{6} \mathrm{~m}^{3}$, mostly tephra accumulating around the tuff cones in area 6 . The cumulative loss since 1967 is $28 \pm 1.5 \times 10^{6}$ $\mathrm{m}^{3}$ for the coastal areas (areas 1 and 2), $1.6 \pm 0.4 \times 10^{6}$ $\mathrm{m}^{3}$ for the tuff cones and sediments (areas 3 and 6) and $1.2 \pm 0.5 \times 10^{6} \mathrm{~m}^{3}$ for the spit (area 5).
A few areas were sampled for assessing the denudation rate. An area of $20,970 \mathrm{~m}^{2}$ within area 2 of the 1967-1974 dDEM, yielded a negative volume of $-0.883 \pm 0.021 \times 10^{6} \mathrm{~m}^{3}$ and calculated denudation rate of $600 \pm 14 \mathrm{~cm} / \mathrm{yr}$. The value agrees well with measured coastal retreat rates for the NW tephra/tuff cone from maps from this period. An area of $13,734 \mathrm{~m}^{2}$ within area 2 of the 1974-2019 dDEM yielded a negative value of $-0.674 \pm 0.014 \times 10^{6} \mathrm{~m}^{3}$ and calculated denudation rate of $100 \pm 2 \mathrm{~cm} / \mathrm{yr}$. The volume is also in good agreement with the calculated coastal retreat for the NW tuff cone for this period. The total denudation rate of the tephra/ tuff cones during the first years from 1967-1974 given the sum of the average erosion rates for areas 3 and 6 and total area of $515,286 \mathrm{~m}^{2}$ yield a denudation rate of $9 \pm 3 \mathrm{~cm} / \mathrm{yr}$. For the same areas from 1974-2019 and a total area of $478,175 \mathrm{~m}^{2}$ we derive a denudation rate of $6 \pm 1 \mathrm{~cm} / \mathrm{yr}$. An area of $19,595 \mathrm{~m}^{2}$ sampled within the consolidated palagonite tuff of Surtur in area 3 in the 1974-2019 dDEM yielded a negative volume of $-0.018 \pm 0.009 \times 10^{6} \mathrm{~m}^{3}$ and calculated denudation rate of $2 \pm 1 \mathrm{~cm} / \mathrm{yr}$. 
Statistical uncertainty is high for a few areas, making their interpretation more difficult. However, the estimated values when compared with independent measurements, show in general good agreement. For example, the 2019 volume of the sediments on the margins of the tuff cones of $0.3 \pm 0.01 \times 10^{6} \mathrm{~m}^{3}$ agrees well with the sum of the net volumes from the dDEMs of area 6 (total $\left.=0.23 \pm 0.2 \times 10^{6} \mathrm{~m}^{3}\right)$. The $1967-1974$ positive volume of $0.430 \pm 0.28 \times 10^{6} \mathrm{~m}^{3}$ of the aeolian sediments on the lava fields of area 4 within an area of $1,122,572 \mathrm{~m}^{2}$ yield average sediment thickness of $38 \pm 24 \mathrm{~cm}$. The $1974-2019$ positive volume of $0.055 \pm 0.08 \times 10^{6} \mathrm{~m}^{3}$ of area 4 divided by an area of $535,010 \mathrm{~m}^{2}$ gives an average sediment thickness of $10 \pm 14 \mathrm{~cm}$. The sum is thus $48 \pm 38 \mathrm{~cm}$ average sediment thickness for area 4 while the measured average thickness is of $49 \pm 7 \mathrm{~cm}$ (Ilieva-Makulec et al. 2015, densely vegetated area excluded).

\section{Volumes of subaerial lithologies revised}

Our results allow for a revision of the estimated total volumes for the main lithologies on Surtsey. The lava fields have a cumulative loss of $22.5 \times 10^{6} \mathrm{~m}^{3}$ and the current volume of uneroded lava is $31.8 \times 10^{6} \mathrm{~m}^{3}$ which gives a total volume in 1967 of about $54 \times 10^{6}$ $\mathrm{m}^{3}$. Together with subsidence and the volume of the lava eroded since 1965 a total initial volume for the subaerial lava flows is likely in the range of $58 \times 10^{6}$ $\mathrm{m}^{3}$, lower than the initial estimate of $70 \times 10^{6} \mathrm{~m}^{3}$. The tuff cones have a cumulative loss of $6.7 \times 10^{6} \mathrm{~m}^{3}$ and with a current volume of $38.6 \times 10^{6} \mathrm{~m}^{3}$ we derive a total volume of about $45 \times 10^{6} \mathrm{~m}^{3}$ in 1967 . The initial volume of the tephra/tuff cones considering the volume loss since 1964 may be around $46 \times 10^{6} \mathrm{~m}^{3}$ which is within the upper range of the initial estimate.

\section{DISCUSSION}

The dynamic geomorphic processes at work in Surtsey since the eruption ceased are vividly portrayed by the dDEM's (Fig. 3). These can be summarized into three processes: 1) The rapid incipient erosion. 2) The prevailing SW coastal wave erosion. 3) Intense wind and runoff erosion and a decrease in sediment availability.

\section{The rapid incipient erosion}

Our results show that rapid erosion characterized the first years of Surtsey, in accord with the field observations (Fig. 3 and Table 2). A better temporal control for the first year's post-eruption would allow for a more accurate assessment, but contemporaneous studies documented a rapid decline in erosion rate, the rate varying between lithologies and erosive processes. As mentioned above, especially noticeable was the decline in coastal wave erosion following the winter of 1967-1968 when up to $140 \mathrm{~m}$ of the southern side of the lava fields eroded away with an average retreat of $75 \mathrm{~m}$ and a total volume loss of $2 \times 10^{6} \mathrm{~m}^{3}$ (Norrman 1970). This volume is twice as high as the average of 1967-1974 and renders an erosion rate 5-6 times the average rate of $0.3 \pm 0.02 \times 10^{6}$ from 1974-2019. Rapid coastal retreat is attributed primarily to the thinner $(<14 \mathrm{~m})$ and less cohesive nature of the distal margins of the lava apron. As noted by Norrman (1972a, 1972b), after passing these margins or terraces, and entering thicker and more cohesive pile of lava, the erosion rate of the lava fields decreased significantly, or to an average of 25-35 $\mathrm{m}$ and a maximum retreat of $40-50 \mathrm{~m}$ the following year. The rate of wave erosion is likely also influenced by the growth of the insular shelf (e.g. Ramalho et al. 2013). The thinner terraces were located near the break of the shelf along the steep submarine flanks of the Surtsey volcano, unprotected from high wave energy loading. According to the bathymetry map of Jakobsson et al. (2009) the width of the insular shelf of Surtsey had grown to about $900 \mathrm{~m}$ in the SW in 2007, extending to $1100 \mathrm{~m}$ when including the mound of Jólnir. The average slope is $1.7^{\circ}$ from the coast to the break of the shelf of Jólnir at about $60 \mathrm{~m}$ depth. The erosion of the satellite mounds down to depths of $50 \mathrm{~m}$ suggests that wave energy is dissipated even to these depths. Therefore, the widening of the shallower shelf is expected to increase wave attenuation and protect the coastal margins.

Our results also show a rapid denudation rate for the tephra/tuff cones the first years. As shown above, we acquire average vertical denudation rate of $9 \pm 3$ $\mathrm{cm} / \mathrm{yr}$ for 1967-1974 while the rate decreased to $6 \pm 1$ $\mathrm{cm} / \mathrm{yr}$ in 1974-2019. Despite the higher statistical uncertainty for the first years, denudation rate about 2-3 times higher than the 1974-2019 average is realistic. Ingólfsson (1982) reported localized measurements on vertical stakes conducted by Sigurður Pórarinsson, that showed that the north side of the Surtungur tephra/tuff cone was lowered by up to $92 \mathrm{~cm}$ in the first three years from 1967-1970 and the top of the Surtur cone by $52 \mathrm{~cm}$. Denudation rate decreased to $10 \mathrm{~cm}$ at Surtungur from 1970-1976 


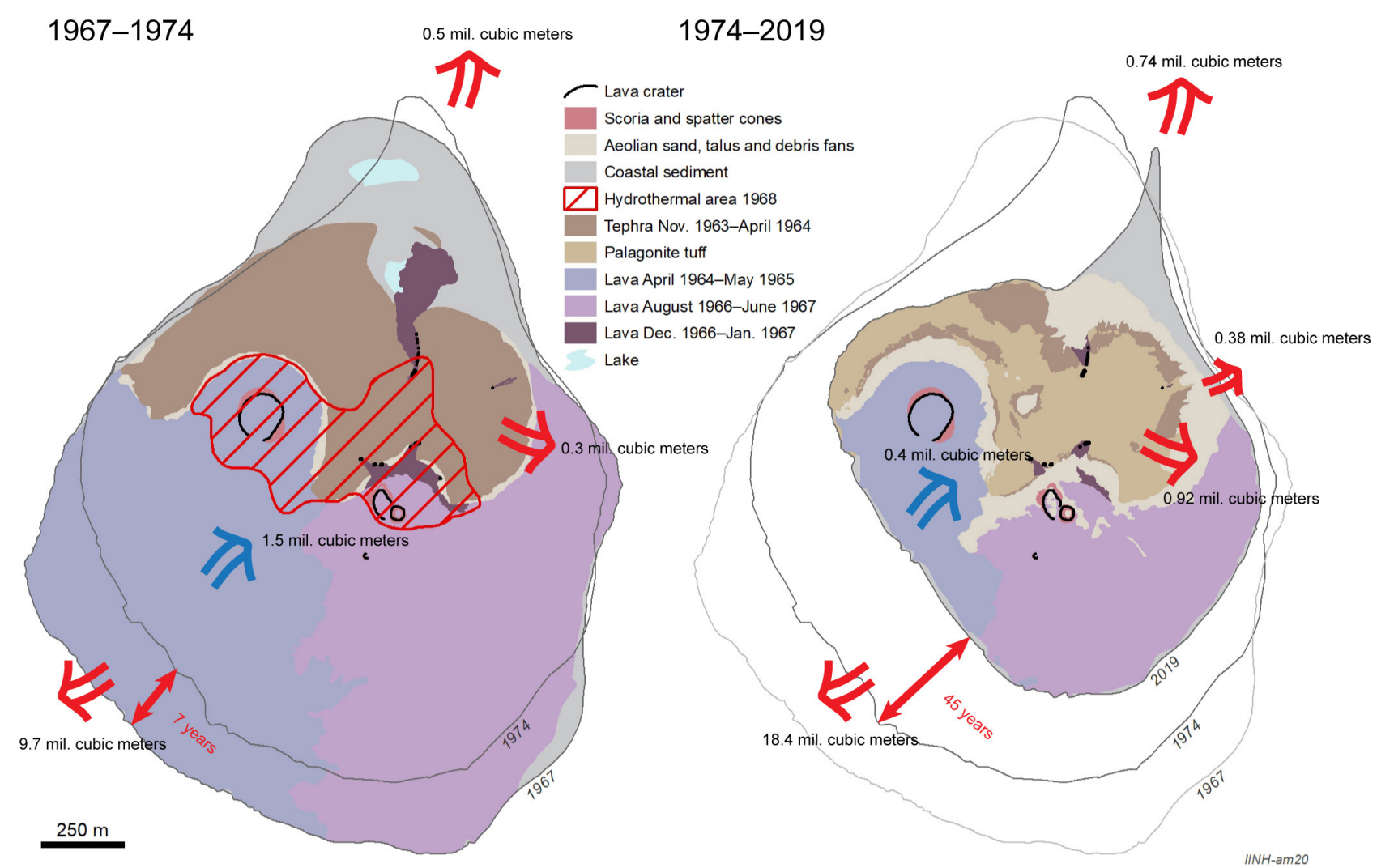

Figure 6. Simplified geological maps of Surtsey as in 1967 and 2019 summarizing the geomorphic and geological changes highlighted in this study. The values with arrows display the most significant volumetric estimates of erosion (red) or sedimentation (blue) from the 1967-1974 and 1974-2019 dDEMs, in million cubic meters (see Fig. 3 and Table 2). Processes in focus are coastal wave erosion (sum of areas 1 and 2), total sedimentation on land, erosion of the spit and wind and runoff erosion of the cones and the marginal sediment (sum of areas 3 and 6). In the figure to the right, the erosion values for the tuff cones and sediments are shown separately.

and to $40 \mathrm{~cm}$ at Surtur; and to $5 \mathrm{~cm}$ at Surtungur from 1976-1979. Rapid denudation rate of the tephra/tuff cones during these first years is explained by the uncompacted and unconsolidated (unaltered) nature of the cones at this time. The subsidence measured by Moore et al. (1992) was about 15-20 cm for the year $1967-1968$ decreasing to $1-2 \mathrm{~cm} / \mathrm{yr}$ to 1991 and compaction of the volcanic material was one of the factors. A hydrothermal anomaly was observed in 1968 in the unconsolidated tephra cones (Fig. 6, Jakobsson 1978), and palagonite tuff was discovered in 1969, meaning alteration was rapidly speeding up diagenesis (Jakobsson 1972), and rates of denudation of the cones declined after the cones became largely palagonitized.

\section{The prevailing $S W$ coastal wave erosion}

Oceanographic studies have confirmed the prevailing SW direction of coastal waves (Romagnoli \& Jakobsson 2015), evident in the prominent erosion of the SW side of the island and the E-NE migration of the spit. The retreat for the last 45 years has progressed at a relatively uniform pace into the lava pile and is about $8 \mathrm{~m} / \mathrm{yr}$ with volume loss of $0.3 \pm 0.02 \times 10^{6} \mathrm{~m}^{3} / \mathrm{yr}$. Of the revised initial subaerial lava volume of $58 \times 10^{6}$ $\mathrm{m}^{3}$, about $45 \%$ has eroded away. The dynamics of failure and retreat of the rocky coast in Surtsey is mainly controlled by the cyclical but persistent wave loading, intensified in heavy storms. The waves hammer the base of the lava cliffs causing flexural fatigue, the strain leading to the propagation of cracks preparing the cliffs for failure (Hapke et al. 2014). The hydraulic action of the waves increases air pressure in the cracks, inducing further propagation of the tip of the cracks (Hansom et al. 2008). A notch develops through abrasion which grows with time to extend an unsupported cantilevered mass (e.g. Sunamura 1992, Young \& Ashford 2008). Failure and collapse of the fractured rocks and unsupported masses form taluses that are entrained as tools in the orbital and turbulent 
motion of the waves prompting further abrasion and speeding the growth of a new notch. Alongside these processes, other weathering mechanisms such as the role of expansion and contraction of cracks with freezing and thawing during winter months and possibly thermal expansion of salts during summer months, are also likely to play a role in the degradation of the lava margins and other parts of Surtsey (e.g. Hansom et al. 2014).

The SW wave current erodes a transect at right angle to the prevailing wave loading. The transect varies in thickness and morphology along the coast, the variation originating from the buildup of the lava shields. Thicker pile of flows builds the proximal areas of the vent (the cone of the shield), while the pile thins out towards distal areas that make the lava apron. Erosion of the SW coast has exposed the thicker lava sequence of Surtungur cone, and the lava morphology there is mostly a pile of thin $(<2 \mathrm{~m})$ surface (overbank) vesicle-poor sheet lobes of smooth or slabby pahoehoe and clinckery a'a types (Fig. 4B, Thordarson 2000). An exception is a $>35 \mathrm{~m}$ thick columnar jointed flow at the base of the sequence (Fig. 4B). The apron is composed of mostly tube-fed hummocky pahoehoe (Thordarson 2000) that feature hollow cavities, caves, and inflation clefts (Fig. 4C and 5B). It is notable that coastal erosion rates seem indifferent to the various morphologies and thicknesses within the lava pile. Norrman (1970) mapped the cracks on the margins of the cliffs from wave loading up to $20 \mathrm{~m}$ into the lava apron in 1968. The cracks mapped in 2019 were found within similar range as in 1968 along the cone and apron. The most distant cracks up to $47 \mathrm{~m}$ are found in the thicker western cliff region (Fig. 2B and 5A) and can be explained as forming at a right angle to the SW current, and/or be the result of the stronger gravitational pull of the thicker cliff section at that location. However, the pace of fracturing of the lava cliffs by the wave action appears to be continuous independent of the thickness of the lava pile. In principle, the base of the lava cliffs is of similar properties and with abrasion and formation of a notch, failure and collapse of the unsupported cantilevered mass takes place independent of the thickness above.

On the other hand, the coastal erosion of the tuff cones, still largely protected by the lava fields, advances at slower rates and only $16 \%$ eroded away. The NW side of Surtungur cone was exposed to wave erosion shortly after formation and waves quickly penetrated the sides of the cone abrading parts of the unconsolidated tephra (Thorarinsson 1968, Norrman 1970, 1974). Steepening of the sides led to slumps and rapid lowering of the west crest of Surtungur, that was about $169 \mathrm{~m}$ a.s.1. in 1965 according to Thorarinsson (1966), to approximately $150 \mathrm{~m}$ a.s.l. in 1968 (Norrman 1970). After 1967 a boulder terrace formed, partly protecting the tephra wall but retreat by erosion was still high reaching $6 \mathrm{~m} / \mathrm{yr}$. With the removal of the boulder terrace sometime in the early 1980 's, wave abrasion has resulted in the formation of a notch and cave (Fig. 4A). With palagonitization, the tuff cones which now form a compact mass without jointing or cleavage (Jakobsson 1978), have become more resistant to erosion, and the current rates of retreat of the western palagonite cliff seems to be in the range of $1 \mathrm{~m} / \mathrm{yr}$.

The boulder coast that extends to the tip of the spit (Fig. 2) gives further evidence of the strength of the prevailing SW ocean currents, where large boulders, up to $2 \mathrm{~m}$ in diameter, have been transported from the southern parts of the island to the spit, a distance over a kilometer. Eyewitnesses reported the tip of the spit to flip from having a hook to the west to having a hook to the east during a day of heavy storm in 2017. Driftwood $100 \mathrm{~m}$ into the central parts of the spit testify to strong flooding events that can sweep material over the berms and far into the spit. Events of this scale can easily account for the disintegration of the spit, and with the retreat of the lava fields with erosion and decrease in sediment on the island, less sediment supplies the spit, which is eroding and shrinking. Since finer particles are more easily washed away with the swash or subject to deflation, the boulder concentration in the spit has increased with time (Norrman 1970, 1972a, Ingólfsson 1982).

\section{Intense wind and runoff erosion and decrease in sediment availability}

Meteorological data from Surtsey and Heimaey show that the prevailing wind direction is easterly and about 30 days per year on average have wind speed exceeding $20 \mathrm{~m} / \mathrm{s}$ (Petersen and Jónsson 2020). The prevailing easterly direction is not obvious from the erosion pattern in Surtsey but could account for the more pronounced erosion of the northeast side of Surtur (Fig. 3 and 4D). Wind erosion intensified in storms causes differential erosion of the palagonitized tephra layers and marked erosion of the inner flanks 
of the craters, including the potholes in the Surtur tuff crater (Fig. 5C), may be the result of vortex shedding (e.g. Bauer et al. 2013) induced by wind-driven currents around the tuff cones.

Seasonal runoff, common during the rainy months of September and October deepens gullies and rills in the unconsolidated tephra and sediments opening new surfaces for erosion (Fig. 4D). Gullies deepen down to the boundary between the unconsolidated tephra and the palagonitized tuff and enlarge where water streams converge (Fig. 4D). Although the average denudation rate of the tuff cones and sediments by wind and runoff reaches $6 \mathrm{~cm} / \mathrm{yr}$, the current erosion of the consolidated palagonitized areas in the tuff cones is estimated at rates of about $2 \mathrm{~cm} / \mathrm{yr}$. In total the denudation by wind deflation and runoff from the tuff cones and sediments removes approximately $0.029 \pm 0.005 \times 10^{6} \mathrm{~m}^{3} / \mathrm{yr}$ of the unconsolidated tephra and sediments.

The lava fields are covered largely by a sediment cover about $50 \mathrm{~cm}$ thick and do not show much evidence of degradation, the only visible changes are on the fragile crust of the hollow shelly pahoehoe flows which at many locations are fragmented, partly by human activity. The scoria cones show only minor evidence of slumps on the crests of the cones but the cumulative material mobilization within both cones since 1967 could amount to $0.033 \pm 0.014 \times 10^{6} \mathrm{~m}^{3}$. A significant change was the collapse of the small cone within the scoria cone of Surtur sometime between 1967 and 1974.

The volume of material eroded by wind or surface waters available for sedimentation or resedimentation on the island is of about $0.03 \pm 0.01 \times 10^{6} \mathrm{~m}^{3} / \mathrm{yr}$ (predominantly material from areas 3, 4, 5 and 6). However, from the 1974-2019 total sediment average, only about $0.008 \pm 0.004 \times 10^{6} \mathrm{~m}^{3} / \mathrm{yr}$ remains on the island, meaning approximately $0.02 \pm 0.01 \times 10^{6}$ $\mathrm{m}^{3} / \mathrm{yr}$ of the eroded material is removed away. Overall, with the prevalence of erosive processes, less sediment is available for plant colonization while vegetation binds and protects parts of the sediment cover for longer periods.

\section{The future of Surtsey}

In terms of predictions for the future development of Surtsey, the 2019 area of $1.2 \mathrm{~km}^{2}$ fits well in the area-based, least-square equation of Jakobsson et al. (2000), but the volume of $0.0707 \mathrm{~km}^{3}$ is larger than predicted by the volume-based equation of Garvin et al. (2000). An erosion rate estimate from the 45-year average given in Table 2 allows for some additional quantification. The erosion rate of $0.02 \pm 0.005 \times 10^{6}$ $\mathrm{m}^{3} / \mathrm{yr}$ of the spit yield a 15-25 year life expectancy for the bulk of the spit. The lava fields with an erosion rate of $0.3 \pm 0.02 \times 10^{6} \mathrm{~m}^{3} / \mathrm{yr}$ have a life expectancy of about 100 years while the palagonitized tuff cones could survive for centuries eroding at a rate of $0.02 \pm 0.004 \times 10^{6} \mathrm{~m}^{3} / \mathrm{yr}$, although wave erosion will speed up the erosion of the palagonitized tuff when the lava fields have eroded away. This is in line with Jakobsson et al. (2000) prediction that the island will likely reach the palagonite core in about 100 years, but the core itself, with an area of about $0.39 \mathrm{~km}^{2}$, may survive for centuries as a palagonite tuff crag.

\section{CONCLUSIONS}

Differencing of high-resolution DEMs allows for quantitative analyses of the erosive and depositional processes that have been active in Surtsey since its emergence. Extreme rate of erosion and sedimentation characterized the first-years post-eruption with the rapid removal of the thin and less cohesive margins of the lava apron by wave erosion. Furthermore, there was rapid erosion of the uncompacted and unconsolidated tephra from the tephra cones by wind and runoff erosion and mass wasting. In the following years, the erosion rate decreased but prevailing SW coastal erosion, runoff and strong winds continue to erode the island, totaling today over $53 \%$ areal loss and $29 \%$ volume loss. The future development of Surtsey projecting current erosion rate predicts that the island will become a palagonite tuff crag in about 100 years.

\section{ACKNOWLEDGEMENTS}

The authors want to thank the rescue team in Vestmannaeyjar for ferrying the expedition over to Surtsey. We also thank the Icelandic Coast Guard for helicopter transport to Reykjavík and for flying around Surtsey for photography. Carsten Kristinsson is acknowledged for the scanning of the historical aerial photographs. We thank Bjarni Sigurðsson for editorial work and Ingvar Atli Sigurðsson for review.

\section{REFERENCES}

Baldursson, S. \& Á. Ingadóttir (Eds.) 2007. Nomination of Surtsey for the UNESCO World Heritage List. Icelandic Institute of Natural History, Reykjavík, 123 p. 
Belart, J.M.C., E. Magnússon, E. Berthier, F. Pálsson, G. Aðalgeirsdóttir, \& T. Jóhannesson 2019. The geodetic mass balance of Eyjafjallajökull ice cap for 1945-2014: processing guidelines and relation to climate. Journal of Glaciology 65, 395-409.

Bauer, B., I. Walker, A. Baas, D. Jackson, C. McKenna Neuman, G. Wiggs \& P. Hesp 2013. Critical Reflections on the Coherent Flow Structures Paradigm in Aeolian Geomorphology. Coherent Flow Structures at Earth's Surface, 111-134.

Calles, B., K. Lindé \& O.J. Norrman 1982. The geomorphology of Surtsey island in 1980. Surtsey Research Progress Report IX, 117-132.

Einarsson, T. 1965. Gosið í Surtsey í máli og myndum. Heimskringla, Reykjavík, 53 pp.

Garvin, J.B., R.S. Williams, J.J. Frawley \& W.B. Krabill 2000. Volumetric evolution of Surtsey, Iceland, from topographic maps and scanning airborne laser altimetry. Surtsey Research $11,127-134$.

Hansom, J.D., N.D.P. Barltrop \& A.M. Hall 2008. Modelling the processes of cliff-top erosion and deposition under extreme storm waves. Marine Geology 253, 36-50.

Hansom, J. D., D. L. Forbes, \& S. Etienne 2014. The rock coasts of polar and sub-polar regions. Geological Society, London, Memoirs 40, 263-281.

Hapke, C.J., P.N. Adams, J. Allan, A., Ashton, G.B. Griggs, M.A. Hampton, J. Kelly, \& A.P. Young 2014. Chapter 9 The rock coast of the USA. Geological Society. London, Memoirs 40, 137.

Höhle, J. \& M. Höhle 2009, Accuracy assessment of digital elevation models by means of robust statistical methods, ISPRS J. Photogramm. Remote Sens. 64, 398-406.

Ilieva-Makulec, K., B. Bjarnadottir \& B. Sigurdsson 2015. Soil nematode communities on Surtsey, 50 years after the formation of the volcanic Island, Icelandic Agric. Sci. 28, 43-58.

Ingólfsson, Ó. 1982. Some observations on the sediments of Surtsey. Surtsey Research Progress Report IX,133-141.

Jakobsson, S.P. 1972. On the consolidation and palagonitization of the tephra of the Surtsey volcanic island, Iceland. Surtsey Research Progress Report VI, 121-129.

Jakobsson, S.P. 1978. Environmental factors controlling the palagonitization of the Surtsey tephra, Iceland. Bull. Geol. Soc. Denmark, Special Issue 27, 91-105.

Jakobsson, S.P., G. Gudmundsson \& J.G. Moore 2000. Geological monitoring of Surtsey, Iceland. Surtsey Research 11, 99-108.

Jakobsson, S.P. K. Thors, Á.T. Vésteinsson \& L. Ásbjörnsdóttir 2009. Some aspects of the seafloor morphology at Surtsey volcano: The new multibeam bathymetric survey of 2007 . Surtsey Research 12, 9-20.

Jakobsson, S.P. \& G. Gudmundsson 2003. Rof Surtseyjar: Mælingar 1967-2002 og framtíðarspá [The marine abrasion of Surtsey, Iceland: areal changes 1967-2002 and future development]. Náttúrufræðingurinn 71, 138-144 (in Icelandic with English summary).

Kjartansson, G., 1966. Stapakenningin og Surtsey [A comparison of table mountains in Iceland and the volcanic island of Surtsey off the south coast of Iceland]. Náttúrufræðingurinn 36, 1-34 (in Icelandic with English summary).

Landmælingar Íslands 2020. www lmi.is.

Loftmyndir ehf. 2020. www.loftmyndir.is.

Lorenz, V. 1974. Studies of the Surtsey tephra deposits. Surtsey Research Progress Report VII, 72-79.

Magnússon, E.; J. M.C. Belart, F. Pálsson, H. Ágústsson, \& P. Crochet 2016. Geodetic mass balance record with rigorous uncertainty estimates deduced from aerial photographs and lidar data - Case study from Drangajökull ice cap, NW Iceland. The Cryosphere 10, 159-177.

McNabb, R., C. Nuth, A. Kääb, \& L. Girod 2019. Sensitivity of geodetic glacier mass balance estimation to DEM void interpolation. The Cryosphere 13, 895-910.

Norrman, J.O. 1970. Trends in post-volcanic development of Surtsey island. Progress report on geomorphological activities in 1968. Surtsey Research Progress Report V, 95-112.

Norrman, J.O. 1972a. Coastal development of Surtsey Island, 1968-69. Surtsey Research Progress Report VI, 137-143.

Norrman, J.O. 1972b. Coastal development of Surtsey Island, 1969-70. Surtsey Research Progress Report VI, 145-149.

Norrman, J.O. 1974. The geomorphology of Surtsey Island in 1972. Surtsey Research Progress Report VII, 61-71.

Norrman, J.O. 1978. Coastal changes in Surtsey Island, 1972-75. Surtsey Research Progress Report VIII, 53-59.

Norrman, J.O. 1985. Stages of coastal development in Surtsey island, Iceland. In Sigbjarnarson, G. (ed.). Proceedings of the Iceland Coastal and River Symposium, pp. 33-40.

Moore, J.G., S.P. Jakobsson \& J. Holmjarn 1992. Subsidence of Surtsey volcano, 1967-1991. Bulletin of Volcanology 55, 17-24.

Pedersen, G. B. M., J. M. C. Belart, E. Magnússon, O. K. Vilmundardóttir, F. Kizel, F. S. Sigurmundsson, G. Gísladóttir \& J. A. Benediktsson 2020. Hekla Volcano, Iceland, in the 20th Century: Lava Volumes, Production Rates, and Effusion Rates. Geophys. Res. Lett. 45, 1805-1813.

Petersen, G.N. \& T. Jónsson 2020. The climate of Surtsey. Surtsey Research 14, 9-16.

Pierrot Deseilligny, M. \& I. Clery 2011. Apero, An Open Source Bundle Adjusment Software for Automatic Calibration and Orientation of Set of Images. ISPRS - International Archives of the Photogrammetry. Remote Sensing and Spatial Information Sciences 3816, 269-276.

Pix4Dmapper 2019. Pix4D SA. www.pix4d.com.

Ramalho, R. S., R. Quartau, A. S. Trenhaile, N. C. Mitchell, C. D. Woodroffe, \& S. P. Ávila 2013. Coastal evolution on volcanic oceanic islands: A complex interplay between volcanism, 
erosion, sedimentation, sea-level change and biogenic production. Earth-Science Reviews 127, 140-170.

Romagnoli, C.\& S. P. Jakobsson 2015. Post-eruptive morphological evolution of island volcanoes: Surtsey as a modern case study, Geomorphology 250, 384-396.

Rupnik, E., M. Daakir \& M. Pierrot Deseilligny 2017. MicMac - a free, open-source solution for photogrammetry. Open Geospatial Data, Software and Standards, 2: 14.

Sturkell, E., P. Einarsson, H. Geirsson, E. Tryggvason, J.G. Moore \& R. Ólafsdóttir 2009. Precision levelling and geodetic GPS observations performed on Surtsey between 1967 and 2002. Surtsey Research 12, 39-47.

Thorarinsson, S. 1964. Surtsey: The new island in the North Atlantic [Surtsey: Eyjan nýja í Atlantshafi]. Almenna Bókafélagið, Reykjavík, 108 p. (in Icelandic with English summary).

Thorarinsson, S. 1966. Some facts about the Surtsey eruption [Sitt af hverju um Surtseyjargosið]. Náttúrufræðingurinn 35, 153-181 (in Icelandic with English summary).

Thorarinsson, S. 1968. The last phases of the Surtsey Eruption [Síðustu pættir Eyjaelda]. Náttúrufræðingurinn 38, 113-135. (in Icelandic with English summary).

Thordarson, T. 2000. Physical volcanology of lava flows on Surtsey, Iceland: A preliminary report. Surtsey Research 11, 109-126.

Sørensen, E.V. \& M. Dueholm 2018. Analytical procedures for $3 \mathrm{D}$ mapping at the Photogeological Laboratory of the Geological Survey of Denmark and Greenland. Geological Survey of Denmark and Greenland Bulletin 41, 99-104.

Sunamura, T. 1992. Geomorphology of Rocky Coasts. John Wiley \& Sons., New York. 302 p.

Walker, G.P.L. 1973. Explosive volcanic eruptions a new classification scheme. Geol. Runds. 62, 431-446.

Young, A.P. \& S.A. Ashford 2008. Instability investigations of cantilevered sea cliffs. Earth Surface Processes and Landforms $33,1661-1677$. 